\title{
Distinction, Necessity, and Proportionality: Afghan Civilians' Attitudes toward Wartime Harm
}

\author{
Janina Dill*
}

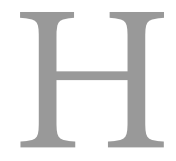

ow do civilian populations react to being harmed in war? Military doctrine and existing scholarship largely agree that civilians turn against the belligerent party to which they attribute civilian casualties and endorse the attacker's opponent. ${ }^{1}$ This can present a strategic challenge. In the twenty-first century, states rarely go to war for aims traditionally associated with the use of military force abroad, such as territorial expansion or permanent occupation. Instead, states often seek to influence how societies organize themselves on a given territory. They thus tend to pursue war aims that depend on the support of the local population. ${ }^{2}$ If civilian casualties enhance support for a warring state's opponent and undermine support for the aims of the attacker, they have the potential to limit the political utility of military power. Although states at war can refrain from deliberately targeting civilians, what we colloquially refer to as "collateral damage" - harm caused to civilians as a side effect of military operations-is all but inevitable.

To manage the strategic implications of civilian casualties, U.S. military doctrine relies on international law. ${ }^{3}$ Counterinsurgency doctrine stresses that the "use of lethal force must respect the legal principles of military necessity, distinction, [and] proportionality." ${ }^{4}$ But do the attitudes of affected civilians toward

\footnotetext{
${ }^{\star}$ I am greatly indebted to Hadi Marifat for providing input into this project in countless ways. I would also like to thank Nik Mohammad Sharif for his invaluable support. For comments on earlier drafts, I am grateful to Anthony Dworkin, Jennifer Erickson, Louise Fawcett, Julia Gray, Todd Hall, Edward Keene, Walter Ladwig III, Robin Markwica, Walter Mattli, Karolina Milewicz, Andrea Ruggeri, Henry Shue, Nina Silove, Steven Simon, Duncan Snidal, and Michael Walzer. This research would not have been possible without the logistical support and hospitality of the Afghan Research and Evaluation Unit and the Afghanistan Human Rights and Democracy Organization. The project was supported by a grant from the John Fell Fund.
}

Ethics \& International Affairs, 33, no. 3 (2019), pp. 315-342.

(c) 2019 Carnegie Council for Ethics in International Affairs

doi:10.1017/So892679419000376 
wartime harm actually vary with these legal rules? Civilians in theaters of U.S. military campaigns are unlikely to be familiar with international law. The expectation that the perceived legitimacy of civilian casualties nonetheless tracks their legality may rest on the assumption that the mentioned legal rules express fundamental moral principles. The namesake moral principles of distinction, necessity, and proportionality have indeed been shown to inform the attitudes of ordinary citizens in the West-for instance, in the United States-toward the harming of others. ${ }^{5}$ However, whether these moral principles also inform the attitudes of civilians toward their own harming in war is entirely unstudied.

This article is the first to examine two crucial questions. First, do the moral principles of distinction, necessity, and proportionality inform civilians' reactions to their own harming in war? Not all harming in war is equally morally wrong or blameworthy. If civilians draw on these three moral principles to make sense of what happened to them, their attitudes will vary with the perceived circumstances and perceived aims of an attack. ${ }^{6}$ Second, do the corresponding rules of international law that guide the conduct of U.S. troops in war resonate with the attitudes of civilians? In this article a legal rule is said to "resonate" with a civilian's attitude if his or her attitude reflects the substantive demand of the legal rule, without the civilian necessarily consciously drawing on or being aware of the rule. Distinction and necessity are similar in law and morality, ${ }^{7}$ but the legal rule of proportionality diverges from the corresponding moral principle. Consequently, if all three moral principles inform civilians' reactions toward their own harming, it follows that the substantive demands of the legal rules of distinction and necessity will be reflected in their attitudes, whereas the legal rule of proportionality will not necessarily resonate with them. ${ }^{8}$

The study discussed here draws on eighty-seven in-depth, semi-structured interviews conducted in Kabul in 2015 with Afghan civilians who were harmed in attacks carried out by coalition troops. ${ }^{9}$ Interviewees who deemed themselves unintended and necessary victims of coalition attacks, in accordance with the moral principles of distinction and necessity, described their attacks as relatively more legitimate than those who thought their harming was deliberate and/or avoidable. The civilians who perceived their harming as unintended and necessary also tended to partially or fully blame parties to the war other than the coalition. Some narratives that civilians recounted about their own harming included comparisons between the coalition's conduct and generalized propositions of right and wrong. This supports the interpretation that the moral principles of distinction 
and necessity informed their attitudes. Accordingly, the substantive demands of the legal rules of distinction and necessity, which express these moral principles, were reflected in the civilians' attitudes. The legal rules of distinction and necessity resonated with the interviewees.

According to the moral principle of proportionality, which originates in the moral doctrine of double effect, the legitimacy and blameworthiness of civilian casualties depends to a large degree on whether they are inflicted in pursuit of a legitimate aim. As none of the interviewed civilians attributed a fully legitimate war aim to the coalition as a whole, the study could not establish whether this moral principle informed their attitudes toward their own harming. According to the legal rule of proportionality, the legitimacy of an attack hinges not on the attack's contribution to a legitimate overall war aim, but on the concrete military importance of the attack. Whereas the interviewed civilians rarely expressed doubts about the intentionality and necessity of their harming, they had for the most part not thought about and were unsure of the military importance of the attack that harmed them. The substantive proposition of the legal rule of proportionality - that is, for an attack that causes civilian casualties, the more important the military advantage being pursued the more legitimate the attack-was hence not reflected in the interviewed civilians' attitudes. ${ }^{10}$ The legal rule of proportionality failed to resonate with them.

This article contributes to our theoretical and empirical understanding of the strategic implications of civilian casualties in two ways. First, it enriches the prevailing theory that says civilian populations will turn against a belligerent party that causes civilian casualties by showing that civilians' attitudes toward their own harming can vary with the perceived circumstances of an attack. ${ }^{11}$ This discovery improves our understanding of the mechanism that connects civilian casualties to strategic outcomes in war. Second, the article's finding that international law partially resonated with the interviewed civilians' attitudes toward their own harming adds nuance to the assumption expressed in U.S. military doctrine that compliance with international law vouchsafes the perceived legitimacy of civilian casualties. The presented findings instead suggest that only the rules of distinction and necessity, which express fundamental moral principles, resonated with the interviewed civilians. International law therefore has an important but ultimately limited role to play in securing the political utility of military force.

In the following section, I first briefly relate the limits to our current understanding of the attitudes of affected civilian populations toward wartime harm. 
Thereafter, I introduce the theory that civilians draw on moral principles when forming attitudes about their own harming, and I articulate expectations for how variation in the perceived circumstances and aims of an attack should be associated with variation in civilians' narratives about their harming and their allocation of blame. I then describe the study's methods, before discussing its findings. The final section highlights the implications and the limitations of these findings for our understanding of the role of international law in securing the perceived legitimacy of military force.

\section{The Attitudes of Affected Civilians Toward Wartime HARM}

Direct investigations of attitudes toward killing in war generally focus on individuals who have never themselves been exposed to war. ${ }^{12}$ What we know about the attitudes of populations in active war zones stems from a rich literature that infers the reactions of noncombatants to their own harming based on the strategic consequences of indiscriminate and deliberate violence against them. The dominant theory holds that "the nation or faction that resorts to warfare against civilians most quickly, most often, and most viciously is the nation or faction most likely to see its interests frustrated and, in many cases, its existence terminated." ${ }^{13}$ The hypothesized reason is that civilian populations are alienated from the party to the war that causes civilian casualties, and therefore endorse or even materially support the attacker's opponent. ${ }^{14}$

The literature on counterinsurgency and "population-centered" warfare has popularized the idea that even nondeliberate harm or collateral damage can bear strategic costs. ${ }^{15}$ To date, the sole empirical inquiry specifically into the strategic implications of such harming as a side effect supports the theory that civilian casualties alienate the local population. Luke Condra and Jacob Shapiro argue that the population in Iraq "punishes" the coalition for "collateral damage" by supporting the insurgency. ${ }^{16}$ However, like the numerous examinations of deliberate and indiscriminate violence against civilians, their study does not investigate Iraqi civilians' attitudes directly. Instead the authors infer the reaction of the population to collateral damage from a sophisticated analysis of the spatial and temporal correlation between civilian casualties and insurgent violence in Iraq.

Elucidating the attitudes of civilian populations toward wartime harm by observing correlations between civilian casualties and strategic outcomes has 
two limitations. First, the mechanism that connects civilian casualties and strategic outcomes remains somewhat obscured. When Condra and Shapiro argue that civilians "punish" their attacker, this might be read to imply that civilians perceive the coalition in Iraq as deserving of blame. However, we know next to nothing about civilians' actual beliefs about a party to the war that harms them. Of course, civilian attitudes toward wartime harm cannot alone account for the strategic implications of civilian casualties. Civilians who live in active war zones, specifically in areas that are contested between belligerents, may not always be free to act in accordance with their own attitudes. Nonetheless, directly examining the beliefs and perceptions of affected populations is an important step in elucidating the mechanism that connects civilian casualties to strategic outcomes.

Second, the literature focused on connecting civilian casualties to outcomes fails to capture a strategically crucial type of potential variation in the attitudes of affected civilians. Existing studies have examined the implications of civilian harming according to a variation in the identity of the attacker ${ }^{17}$ and differences in the military control of the attacker. ${ }^{18}$ They have not investigated the potential implications of a variation in the circumstances and aims of attacks attributed to the same belligerent party in the same war. Notably, a number of recent studies suggest that Western populations vary in their attitudes toward wartime casualties, depending inter alia on the circumstances and aims of attacks that harm civilians. ${ }^{19}$ Particularly when it comes to U.S. counterinsurgency campaigns, uncovering the implications of this type of variation is a crucial strategic quest. If all civilian casualties caused by such campaigns equally undermined civilian support, the inevitability of collateral damage would cast doubt over the very utility of using force for the pursuit of political aims that partly depend on the support of the local population. $^{20}$

U.S. counterinsurgency doctrine highlights the danger that civilian casualties undermine victory in a campaign that has "the population at its focus." Although the Joint Chief of Staffs joint publication on counterinsurgency suggests that local populations vary in how they react to civilian casualties, ${ }^{22}$ it does not indicate what determines this variation. Instead, the document makes two recommendations for how U.S. troops on the ground should manage what it calls the collateral damage "dilemma": first, to look at civilian casualties "through the eyes of the population" 23 and, second, to "comply with the law of war." ${ }^{24}$ Every use of "lethal force must respect the legal principles of military necessity, distinction, [and] proportionality." 25 U.S. military doctrine hence assumes that civilian 
harm stands a better chance of being perceived as legitimate by the civilian population if it conforms to these legal rules.

Notably, the doctrine does not claim that the legality of an attack matters to the affected civilians. ${ }^{26}$ Why then should international law be an appropriate guide for U.S. military forces in the quest to secure the legitimacy of civilian casualties in "the eyes of the population"? Prior shared beliefs about appropriate state conduct often form the basis of what becomes a rule of international law. ${ }^{27}$ The categories according to which international law delineates permissible from impermissible killing may thus also be the categories according to which observers generally distinguish legitimate from illegitimate wartime harm. ${ }^{28}$ Indeed, the legal rules of distinction, necessity, and proportionality partly express fundamental moral principles that have been shown to inform ordinary citizens' attitudes toward harming in peacetime. ${ }^{29}$ It is plausible that these everyday moral principles also inform civilians' attitudes toward acceptable and unacceptable harming in war. A general convergence between the legality and the perceived legitimacy of civilian casualties is therefore not an unreasonable expectation.

At the same time, the international laws of war are a product of political compromise. They also reflect pragmatic considerations necessary to secure compliance on the battlefield. ${ }^{30}$ As a result, the legal rule of proportionality diverges from the underlying moral principle of the same designation, as explained in further detail below. Moreover, what political elites and Western populations consider legitimate harm in war may diverge from what civilians affected by the carnage of hostilities find acceptable. We do not know whether the moral principles that structure the attitudes of detached observers also inform the attitudes of civilians toward their own harming in war.

\section{Distinction, Necessity, Proportionality, and Civilians' Attitudes}

If civilians' attitudes toward wartime harm were informed by the moral principles of distinction, necessity, and proportionality, we would expect an association between the perceived circumstances and aims that make an attack morally permissible and civilians' perception of an attack as legitimate and blameless. Specifically, if an attack's perceived circumstances and aims conformed to the three moral principles, the affected civilians would likely consider the attack legitimate and the attacker blameless, or at least relatively so. In contrast, if an attack's 
perceived circumstances and aims were in violation of one or more of these moral principles, affected civilians would consider the attack less legitimate and put greater blame on the attacker for its consequences. If moral principles informed civilians' attitudes, we would also expect that the substantive propositions of legal rules would be reflected in these attitudes, but only to the extent that these rules accord with the underlying moral principles.

The most fundamental rule of wartime conduct is the prohibition on intentionally attacking civilians and civilian objects. ${ }^{31}$ Neither legal rules nor moral principles, however, afford civilians absolute freedom from wartime harm. Both the moral principle and the corresponding legal rule of distinction protect noncombatants only from intentional attack. The differentiation between intentional and unintentional harm echoes a more general moral principle. Beyond the specific context of war, it is a widely supported moral precept that a wrong committed deliberately is, all things considered, worse than the same wrong committed unintentionally. ${ }^{32}$ Research in moral psychology has shown empirically that individuals allocate blame more readily for harms that are perceived as deliberate. ${ }^{33}$ If moral principles inform civilians' attitudes, their perception of their harming as unintentional will be associated with the assessment of an attack as less illegitimate and the attacker will incur less blame. Moreover, the legal rule of distinction will resonate with affected civilians' attitudes.

International law permits launching an attack intended to neutralize a military target even if it will also kill civilians as an unintended but foreseeable side effect. For such incidental civilian harm to be legal, it has to be necessary to achieve the military advantage the attack is pursuing. ${ }^{34}$ From a moral point of view, it is widely understood that a wrong that could easily have been avoided is, all things considered, morally worse than the same wrong committed under circumstances that left the perpetrator no choice. Moral psychology has likewise established that we take into account whether a perpetrator took care to avoid harm when allocating blame. ${ }^{35}$ Thus, if moral principles inform civilians' attitudes, their perception of their harming as necessary will be associated with the assessment of an attack as less illegitimate and the attacker will incur less blame. Moreover, the legal rule of necessity will resonate with civilians' attitudes.

If civilian casualties are unnecessary, they are both illegal and morally wrongful. That does not mean, however, that civilian casualties that could not be avoided in the pursuit of a military target are therefore fully legal and morally justified. They also have to be proportionate. The moral principle of proportionality originates in 
the doctrine of double effect, which stipulates that it may be morally justified to cause a bad effect (like killing innocent bystanders) in the pursuit of a good effect (such as saving a greater number of innocent persons or averting a greater moral evil) if the bad effect is proportionate to the good effect. If moral principles inform civilians' attitudes to wartime harm, the perception of the attacker as fighting for a legitimate overall war aim will be associated with the assessment of an attack as less illegitimate. A party to the war deemed to be fighting for a legitimate war aim will incur less blame for civilian harm.

Unlike distinction and necessity, the legal rule of proportionality diverges from the more general moral precept. To be legal, incidental civilian harm has to be proportionate only to the military advantage that a specific attack seeks to achieve. The military advantage that a specific attack pursues may have a morally good effect because the war overall pursues a morally just aim and the attack contributes to achieving victory. In most wars, however, at maximum one side is fighting for a just aim. Yet international law imposes the same restrictions on all parties to the war. $^{36}$ Whether and how much incidental harm international law allows an attacker to inflict is legally independent from the overall aims a military campaign pursues. If civilians' reactions to wartime harm somehow echoed the legal proportionality rule, the belief that the attack in question has a high military importance would contribute to an assessment that it is less illegitimate, and the attacker would incur less blame. If, on the other hand, international law's resonance with civilians' attitudes is due to the law reflecting the corresponding moral principles, we will only observe this association for individuals who believe that their attacker is pursuing a legitimate war aim. ${ }^{37}$

It is important to note that the theory that the moral principles of distinction, necessity, and proportionality inform civilians' attitudes does not imply that we should think of the relationship between the perceived circumstances and aims of an attack and civilians' attitudes as causal. The perception of an attack as intended to harm civilians, for instance, is not a counterfactual trigger that leads to a switch in a civilian's assessment of an attack from legitimate to illegitimate, or from relatively more to relatively less legitimate. In some cases, the assessment of an attack's legitimacy may inform whether the harm caused by the attack is perceived as intentional as much as the perception of harm as intentional informs the belief about the attack's legitimacy. Determining what comes first, for instance, by designating the perception of intentionality as the cause 
and the legitimacy assessment of the attack as the effect, would wrongly imply an ontological separation between and a temporal order of these two beliefs.

A better way of thinking about the hypothesized associations between the perceived circumstances and aims of an attack and a civilian's legitimacy judgment or allocation of blame is in terms of the coherence between the factual and the normative interpretation of an attack. The hypotheses suggest that civilians attribute coherent meanings to the factual circumstances and aims of an attack (Was it in fact directed against me? Was my harming avoidable?) and its normative evaluation (Was the attack legitimate? Do I blame the attacker?). The meaning of "unintentional harm" coheres with the meaning of "less illegitimate attack" and the meaning of "intentional harm" with that of "more illegitimate attack" in virtue of the principle of distinction. Civilians' joint attribution of these meanings would therefore be indicative of the civilians making moral judgments based on the perceived circumstances and the perceived aims of "their attack."

\section{Studying the Attitudes of Affected Afghan Civilians}

This article puts the hypothesis that civilians' attitudes toward wartime harm vary with the perceived circumstances and aims of an attack to the hardest possible test. It examines the attitudes of the individuals least likely to perceive wartime harm as anything but fully illegitimate and blameworthy: civilians who have themselves experienced physical injury or have lost family members as a direct result of warrelated attacks. In order to obtain as rich a picture as possible of variations in the narratives that civilians tell about their attacks, I held constant the belligerent who inflicted the harm by interviewing only civilians who attributed their harming to the international coalition in Afghanistan. ${ }^{38}$ The question of whether legal rules resonate with civilians' attitudes is also more relevant to a belligerent whose conduct is actually guided by these rules. ${ }^{39}$ In Afghanistan the legal rules of distinction, necessity, and proportionality guide only the coalition's conduct, ${ }^{40}$ as the Taliban reject them as a Western invention. ${ }^{41}$ I also refrained from interviewing civilians who had not directly experienced war-related harm. The goal of this study is not to elucidate the difference that being harmed makes for the substance of civilians' attitudes toward a belligerent party, but to show how different beliefs about an attack's circumstances inform judgments of legitimacy and blame.

The study consists of eighty-seven face-to-face, in-depth interviews in Kabul with Afghan civilians directly affected by war-related violence. Interviewees 
were recruited from two camps for internally displaced persons. ${ }^{42}$ War-related violence had displaced them to Kabul, between 2008 and 2015, from the southern provinces of Helmand and Kandahär. The events that displaced them mostly fell into four broad categories: air strikes, cross-fire incidents, direct shootings, and indirect artillery fire. Interviewees were asked to recount the event(s) that led to their displacement before they were asked structured questions regarding their beliefs about the attack and the parties to the war. Although the accounts have been subjected to a general plausibility check, it would be impossible to verify them. This research does not aim to shed new light on the development of the war in Afghanistan-on the facts as it were-but rather to investigate civilians' perceptions and beliefs. The factual accuracy of the accounts is therefore less important than their faithfulness to the interviewees' actual views.

Great care was taken not to give interviewees any perceived reasons to misrepresent their views. Interviewees were assured of their anonymity and informed about the scholarly nature of the study, the author's lack of affiliation with any government or party to the conflict, and the absence of rewards or repercussions associated with giving their opinion. Interviews were conducted away from the camps for displaced persons in the building of an independent, local civil society organization, in a room with only the author, one or two translators, and one interviewee present at a time. ${ }^{43}$ The interview setup was designed to build a sense of trust and to reduce the risk of the interviewees deliberately distorting their views. Nonetheless, we remained aware of the traumatic nature of the events that the interviewees recounted and the complexity of the questions we asked. Interviews were therefore not limited in time and interviewees were encouraged to tell their story without interference or interruption before being asked questions. Interviewees initially accounted for what had displaced them to Kabul, and were given no indication of the substantive objectives of the study in order to avoid creating pragmatic pressure. Finally, the structured questions were repeated, often in different ways, to allow interviewees to work through them both emotionally and intellectually. ${ }^{44}$

Internally displaced persons are not necessarily representative of all civilian war victims. Moreover, the group of interviewees is not a faithful reflection of the entire Afghan civilian population in terms of age, gender, or ethnicity. ${ }^{45}$ Although the group is representative of the ethnic makeup of both the Helmand and Kandahār provinces, ${ }^{46}$ it is less certain that it is fully representative of the tribal makeup of the two provinces because reliable statistics are unavailable 
for these populations. In both provinces, the majority of tribes belong to the Durrāni clan/confederation, with fewer tribes and subtribes belonging to the Ghilzay clan/confederation. While the Ghilzay traditionally formed the leadership of the Taliban and were underrepresented in the government, the current president of Afghanistan, Ashraf Ghani, is a Ghilzay, and anti-government forces now include Durrāni and Ghilzay commanders equally. This is evidence for the fact that support for the Taliban/government no longer aligns with tribal structures. ${ }^{47}$

It is important to note, however, that this study does not seek to make generalizable claims about the substance of Afghan civilians' attitudes toward the coalition, which would require a representative sample of the Afghan population. Instead, the study inquires into the role of beliefs about an attack in the formation of civilians' attitudes. While individuals of different generations or tribes may perceive the circumstances of the same attack in different ways, how a particular belief about an attack's circumstances or aims is processed to inform an individual's attitude is unlikely to vary systematically with age, gender, or tribal membership..$^{48}$ That is not to say that the same beliefs about an attack necessarily lead to the same attitudes. Rather than demographic factors, for which one could seek representativeness in a group of individuals, it is likely that more subtle dispositional factors account for differences in how a particular belief (for instance, about the intentionality of harm) informs an individual's attitudes. ${ }^{49}$ The following section focuses on the question of whether the three moral principles of necessity, distinction, and proportionality informed the interviewees' narratives about their attack and their allocation of blame, and the section thereafter discusses the implications of these findings for the resonance of the corresponding legal rules.

\section{Moral Principles, Perceived Legitimacy, and Allocation OF BLAME}

\section{Distinction}

According to the moral principle of distinction, intentionally harming civilians is more wrongful than unintentional harming. If this principle informed civilians' attitudes toward their own attack, the perception of an attack as intended to harm civilians should be associated with narratives that cast the attack as less legitimate. Seventy out of eighty-seven (8o percent) of the interviewed Afghan civilians 
thought they had been harmed unintentionally as a side effect of an attack against the Taliban or an armed insurgent group..$^{50}$ Fourteen out of eighty-seven (16 percent) suggested that the coalition had deliberately set out to harm them. The remaining three interviewees were unsure about intentionality. Narratives that civilians relied on to make sense of their attack conveyed a clear association between the perceived intentionality and perceived legitimacy of the attack.

Among interviewees who reported that they had been harmed unintentionally, two types of narratives pertaining to the attack's legitimacy emerged. The first type referenced the general need in war to attack the enemy in order to win even if it meant harming civilians. A number of interviewees used the saying "No one distributes sweets in a war," by way of explaining why they thought the coalition had launched the attack that injured them or harmed their relatives. I term this the "military pragmatism" narrative. A second type of narrative focused on the belief that the coalition had been under attack from the Taliban prior to the strike. As part of this narrative, interviewees often related that the Taliban had been hiding in a civilian home, from which they attacked a convoy of coalition troops. This prompted a coalition air strike, which harmed civilians in the home and the surrounding compound. Interviewed civilians who deemed the resulting civilian casualties unintentional tended to conceive of these air strikes as reasonable responses to the initial attack. "The Taliban fired first. If someone does that to me, I will fire back." ${ }^{11}$ I call such accounts the "self-defense" narrative.

Different accounts dominated the stories told by the civilians who deemed themselves targets of intentional harm. One type of narrative focused on the character of the attacker. Coalition troops were described as prejudiced foreigners who did not value Muslim lives: "Americans are against Muslims. For them, Taliban and civilians are the same." 52 "They are here to kill us and destroy our houses." 53 "They think we are animals." ${ }^{4}$ I term this the "anti-Muslim" narrative. Many interviewees who resorted to this narrative were harmed in direct shootings. Other interviewees evoked the scenario of the Taliban hiding in a civilian home, from which they attacked coalition troops, which prompted a coalition air strike. Rather than drawing on the self-defense narrative, however, these individuals surmised that the air strike had deliberately targeted them based on the coalition troops' false assumption that all civilians were supportive of the Taliban. "They think we are helping the Taliban, so they want to punish us." "They said we are Taliban. They suspect everyone." ${ }^{\text {6 }}$ I term this the "unfair punishment" narrative. 
One might counter the inference that the moral principle of distinction informed civilians' attitudes with the argument that it is a matter of logic that interviewees in the intentional harm group did not rely on the military pragmatism or self-defense narratives. A deliberate attack against civilians may be less likely to contribute to winning a war or to serving defensive purposes. Civilians who reported being targets of intentional attack, however, often allowed for the possibility that it was militarily useful to attack civilians because this would discourage support for the Taliban. One, for instance, suggested that "they hope that we kick the Taliban out of our houses if they kill our children." 57 These narratives nonetheless cast such attacks as illegitimate. Similarly, civilians who thought that they were intentionally attacked with an air strike called in by troops on the ground did not deny that coalition forces had been under attack first. Those who answered yes to the question of whether they thought their harming was intended, however, invariably cast such attacks as "unfair punishment."

Table 1. Perceived intentionality of harm and interviewees' allocation of blame

\begin{tabular}{lccccc}
\hline \hline & \multicolumn{5}{l}{ Allocation of Blame } \\
\cline { 2 - 6 } & $\begin{array}{l}\text { Coalition } \\
\text { only }\end{array}$ & $\begin{array}{l}\text { Other side/ } \\
\text { Taliban only }\end{array}$ & $\begin{array}{l}\text { Coalition and } \\
\text { other side }\end{array}$ & Unsure \\
\hline $\begin{array}{c}\text { Perceived } \\
\text { Intentionality }\end{array}$ & $\begin{array}{c}\text { Unintentional } \\
(\mathrm{n}=70) \\
\text { Intentional } \\
(\mathrm{n}=14)\end{array}$ & 2 & 24 & 41 & 3 \\
& 6 & 0 & 6 & 2 \\
\hline \hline
\end{tabular}

${ }^{\star}$ This table reflects the results of three separate questions. All subjects were first asked, "Do you blame the attacker for the harm they did to you/your loved ones?" We then asked one of two follow-up questions based on a subject's response to this first question. Interviewees who answered yes to the first question were then asked, "Do you blame anyone besides the attacker for the harm they did to you/your loved ones?" Interviewees who answered no to the first question were then asked, "Do you blame anyone else for the harm they did to you or your loved ones?" For a list of relevant questions, see the online supplement, which outlines the form and content of the study. ${ }^{58}$

A similar association emerged between the perceived intentionality of civilian harm and the allocation of blame across parties to the war, as summarized in Table 1. A majority of interviewees in both groups placed at least some blame on the coalition for the harming. Forty-three out of seventy (61 percent) of those who thought they had been harmed unintentionally, and twelve out of 
fourteen (86 percent) of those who thought they were targeted intentionally, answered affirmatively when asked whether they blamed the attacker. Interestingly, however, when asked whether they blamed anyone besides the coalition, forty-one of the forty-three (95 percent) who thought they had been harmed unintentionally and blamed the coalition suggested the other side deserved some blame as well. One interviewee explained, "I blame the Americans. But the first ones to blame are the Taliban. They caused the situation by coming into our house, but it was an American plane and they knew there were women and children. So, I blame them too." ${ }^{59}$ Only two interviewees among those who viewed themselves as unintentionally harmed said the coalition alone bore the blame for the unintentional harm inflicted on them or their family. In contrast, six of the fourteen interviewees who deemed themselves victims of intentional harm attributed sole blame to their attacker and six more allowed for the other side to share in the blame.

The responses of those who did not place any blame on their attacker also exhibit an obvious association with intentionality. All twenty-four interviewees who thought they had been harmed unintentionally and who had initially said they did not blame the attacker solely blamed the Taliban or another antigovernment party. Exemplifying this view, one interviewee stressed that "if [the Taliban] didn't fire, the Americans would not have sent the plane." ${ }^{60}$ In contrast, none of the interviewees who deemed themselves victims of intentional harm completely released the coalition from blame. ${ }^{61}$

The association between perceived intentionality and the narratives that civilians told about their attack is on its own not conclusive of moral principles actually informing their attitudes, in the sense that civilians consciously draw on them. Blame, of course, is an expression of moral opprobrium, but I explicitly asked civilians whether and how they allocated blame for the harm done to them. It would be a stronger indication that moral principles actually inform civilians' attitudes toward their own harming if the narratives that civilians related without guidance revealed that they draw on generalized propositions about right and wrong to make sense of what happened to them. Of course, not all interviews featured unprompted explicit moral reasoning, but several did.

Some interviewees explicitly tied the accounts of their own attacks to general propositions about the role of intentionality in making harm more wrongful. One interviewee stated that it was "much worse to kill an innocent person directly." In contrast, killing someone in self-defense could be permitted: "Once 
the Taliban shoot at them, I would say [the U.S. troops] are allowed to shoot back." ${ }^{62}$ Another interviewee elaborated, "I thought maybe they deliberately targeted us, but they sent a delegation and it became clear they were not happy with what had happened. It would have been worse if they had no respect for our lives." When I asked why it would have been worse if the harm had been directed at them, he said that "on the day of judgment it will matter." 63 Both narratives associated with intentional harm often featured the assertion that American troops had no respect for Afghan civilians. ${ }^{64}$ One argument of why intentional harming is morally worse than unintentional harming is indeed that it expresses a lack of respect for the victim's dignity.

\section{Necessity}

What about the moral principle of necessity? To recall, the principle of necessity considers unintentional but foreseeable civilian harm more morally wrongful if it could have been avoided. I therefore asked the seventy civilians who thought they were harmed unintentionally whether they thought the harm could have been avoided if the coalition had been more careful in the execution of the attack. Fifty-one out of seventy (73 percent) said the harm was unnecessary and could have been avoided; seventeen ( 24 percent) stated that the harm was probably or definitely unavoidable; and two were unsure. Many interviewees who thought their harming was unavoidable emphasized the chaotic circumstances of the attack, in terms of the pace and obscurity of who was firing at whom when insurgent fighters commingled with civilians: "It is not possible to be careful in this war. Taliban are inside our houses and the U.S. forces can't distinguish Talib from local people, especially during the night." ${ }^{65}$ In contrast, a common explanation for why civilians thought their harming could have been avoided highlighted the superior military capabilities of the United States. Several interviewees volunteered stories about the kind of objects that a U.S. pilot could allegedly distinguish from their vantage point. For instance: "We have been told that American technology is so advanced that they can see a needle from the air. Why then don't they distinguish civilians from Talib?" chickens from the air, how come they can't recognize women and children?"67

Almost all civilians who deemed themselves unintended and unavoidable victims of harm were in the group who subscribed to the self-defense narrative. The perceived necessity of harming was also associated with how interviewees allocated blame for their harming. As Table 2 shows, of those who maintained 
Table 2. Perceived necessity of harm (for those who viewed their harming as unintentional) and interviewees' allocation of blame

\begin{tabular}{llllll}
\hline \hline & Allocation of Blame & & & \\
\cline { 2 - 6 } & & $\begin{array}{l}\text { Coalition } \\
\text { only }\end{array}$ & $\begin{array}{l}\text { Other } \\
\text { side only }\end{array}$ & Both & Unsure \\
\hline Perceived Necessity & Necessary $(\mathrm{n}=17)$ & 0 & 10 & 6 & 1 \\
& Avoidable $(\mathrm{n}=51)$ & 2 & 14 & 35 & 0 \\
& Unsure $(\mathrm{n}=2)$ & 0 & 0 & 0 & 2 \\
\hline \hline
\end{tabular}

that the coalition could have avoided their "collateral" harming, fourteen out of fifty-one (27 percent) did not blame the attacker but instead blamed the other side. In contrast, ten out of seventeen (59 percent) who thought their harming was unavoidable did not at all blame the attacker but fully blamed the other side. The six civilians who deemed their harming both unintentional and necessary but who did not fully absolve their attacker of blame all partially blamed the other side. None of them solely blamed the coalition.

The interviewees who believed they were harmed as an unintended but avoidable side effect of military operations exhibited remarkably nuanced attitudes. Many differentiated between the legitimacy of attacking the enemy in war for the purpose of defending troops under fire and the blame that they nonetheless levelled against the attacker because of the latter's failure to minimize harm to civilians. As one interviewee related, "[The Americans] were defending themselves. They didn't mean to kill us. The Taliban were fighting them in the village, but what I blame them for is the airstrike. They could have used a bomb with less fire." 68

To summarize, there was a clear association between the perception of distinction and necessity on the one hand and the assigning of blame on the other. Those who perceived themselves as the victims of harm by the coalition as an unintentional and unavoidable side effect tended either to allocate partial blame to other parties or to completely absolve the attacker of blame. None of the civilians who perceived themselves as unintended and unavoidable victims of harm, in accordance with both principles of distinction and necessity, solely blamed the coalition. These findings add nuance to the prevailing theory that suggests that civilians uniformly punish the party to which they attribute civilian harm. Instead, the allocation of blame varied with the perceived circumstances of the attack. 


\section{Proportionality}

Recall that according to the moral principle of proportionality, to be justified, civilian harm has to be not only unintended and necessary but also proportionate to the attack's contribution to the morally just aims that a war pursues. When asked about the legitimacy of the aims of the warring parties, none of the interviewed civilians could identify a coalition aim that they thought to be fully legitimate. ${ }^{69}$ Rather, they identified aims such as uprooting terrorism and gaining control of the country. ${ }^{70}$ This lack of variation in the perceived legitimacy of the coalition's overall war aims made it impossible to gauge whether the perceived legitimacy of such aims would have been associated with the consideration of an attack as relatively more legitimate or with a further mitigation of blame.

Given that I could not determine whether the moral principle of proportionality informed the interviewees' attitudes toward their own harming, toward the end of the interviews I asked whether in general interviewees considered it legitimate to kill civilians in pursuit of a legitimate war aim. Sixty-nine of the seventy-seven interviewees who answered this question did so affirmatively. ${ }^{71}$ Many emphatically stressed that a belligerent who brought peace, stability, or security would be permitted to cause civilian casualties and not incur blame. "People in Helmand are ready to sacrifice people. I would sacrifice my sons for peace, but their purpose is not peace." ${ }^{72}$ As one saw it, "If the Americans brought peace, everyone would praise and pray for them even in spite of what has happened."73 Another explained, "I accept that some ordinary people will die in war. If it ends in peace and removed the Taliban, I would accept this." " 4 One man was less sure: "If they bring security, they can stay as long as they want, but what if they kill people for nothing? That is wrong." 75 Among the eight interviewees who denied the permissibility of killing civilians in pursuit of a legitimate war aim, some expressed doubts that continued hostilities could achieve such aims. "There are more [than] 50,000 people [who] were living in Sangin district. Nearly one-fourth were killed and even more are displaced, yet there is no peace." ${ }^{\prime 6}$ Others offered more principled rejections of the permissibility of killing civilians, such as: "It is not right at all. No one should be killed for the sake [of] peace and security." 77

Of course, even the affirmative answers echo only one dimension of the principle of proportionality: the general permissibility of foreseeably killing innocent bystanders as a side effect of pursuing a morally just end. Strictly speaking, the principle of proportionality also demands a balance between the amount of civilian harm caused in a particular attack and the importance of the attack's 
contribution to the achievement of a legitimate overall war aim. Further research is required to establish whether this balancing requirement informs the attitudes of civilians affected by war. Moreover, it is important to stress that the interviewees were expressing their views in response to what-if questions. In other words, here the proportionality principle informed their attitudes toward civilian casualties in Afghanistan in general, not specifically toward their own harming.

Is the legal rule of proportionality reflected in the interviewees' attitudes? To recall, the legal rule of proportionality, in opposition to the moral principle, does not require that civilian harm is proportionate to legitimate overall war aims; it is independent of whether a military campaign has a just aim. Instead, international law demands only a balance between the concrete military importance of the attack and the civilian harm it will cause. Whereas only a few interviewees were unsure about the intentionality and necessity of the harm caused to them, most were unsure or did not have clearly formed views about the attack's military importance. Beliefs about what aim an attack may have had, such as defending coalition troops or targeting Muslims, played prominent roles in civilians' narratives and their perceptions of an attack as legitimate or not. ${ }^{78}$ Yet interviewees had not thought about the importance or military value of achieving these aims in the specific context. When asked, many averred that they did not or could not know how important their attack was for the coalition's military success. ${ }^{79}$

\section{IMPLiCATIONS FOR THE ROLE OF INTERNATIONAL LAW}

The discovered association between the perceived intentionality and necessity of harming, on the one hand, and civilians' narratives and allocation of blame for their own harming, on the other, indicates that the substantive demands of the legal rules of distinction and necessity were reflected in the interviewed civilians' attitudes. In contrast, the substantive proposition of the legal rule of proportionalitysuggesting that an attack that harms civilians is more legitimate the greater the military advantage that it pursues-was not reflected in the interviewed civilians' attitudes. In other words, whereas the legal rules of distinction and necessity resonated, the legal rule of proportionality did not. This is not to say that the interviewed civilians explicitly rejected or disagreed with the legal rule of proportionality. Rather, its substantive demand did not inform their reactions to being harmed.

Can we infer from this that an attack that conforms to the rules of distinction and necessity is more likely to be perceived as legitimate by the local population, 
in line with the assumption expressed in U.S. counterinsurgency doctrine? One objection here is that civilians' judgments of legitimacy and their allocation of blame were based on how they perceived the circumstances of an attack, not on its actual circumstances. As a result, one might argue that this study does not give grounds to the argument that belligerents should comply with the rules of distinction and necessity, because a legally compliant attack may not always be perceived as such. While it is true that this study did not set out to investigate differences between the actual and the perceived conduct of an attacker, it is plausible that the two often correspond. Moreover, as I demonstrate below, the possibility that civilians wrongly perceive the circumstances of an attack increases rather than decreases the importance of complying with international law, if a belligerent party's goal is for civilian casualties to be relatively more legitimate in the eyes of the population.

The previous section reported that some civilians perceived harm caused by airstrikes called in by coalition troops on the ground as an unintentional side effect of self-defense. Other civilians, in contrast, perceived harm inflicted in the same way as intentional. Civilians' prior beliefs about coalition forces may play a role in accounting for this divergence in interpretations of similar scenarios. Studies in political psychology have highlighted that we see the world through a prism of our prior beliefs, which act as a cognitive schema. ${ }^{80}$ We have a need for consistency, and we therefore have a tendency to interpret events in a way that supports our prior beliefs. ${ }^{81}$ If civilians' prior beliefs about a party to war act as a schema through which they interpret the circumstances of an attack, then they are, prima facie, more likely to perceive legally compliant attacks correctly if they already have a positive view of the coalition. In this reading, civilians are more likely to misperceive legally compliant harm if they believe the coalition generally mistreats civilians. Prior beliefs about a party to war are, of course, informed by the party's prior conduct. Thus, the fact that intentional or avoidable civilian casualties influence the interpretation of future coalition conduct adds urgency to being consistently compliant with the legal rules of distinction and necessity.

At the same time, prior beliefs about a party to the war may also be systematically connected to an individual's political preferences or social environment. ${ }^{82}$ This raises the question of whether an attacker's compliance with distinction and necessity ever makes a difference for how the circumstances of an attack are perceived when those circumstances defy the civilian's expectations of the attacker's conduct. Research in political psychology suggests that two factors 
make it more likely that individuals accept an interpretation of events that contradicts their prior beliefs. First, the more overwhelming the information is that they cannot assimilate to a prior schema-in other words, when the factual circumstances very obviously challenge their existing schema-the more likely they are to accept an interpretation of events that defies their expectations. ${ }^{83}$ This suggests that the more obvious it is that civilian casualties are legally compliant, meaning unintended and unavoidable, the more likely they may be perceived as such-a civilian's divergent expectations of a warring party's conduct notwithstanding. The more open to interpretation are the circumstances of an attack, the more important may be a civilian's prior beliefs about an attacker's conduct for the interpretation of the attack. Accordingly, among the four types of attacks that displaced the interviewed civilians, air strikes were the most often subject to divergent interpretations regarding the intentionality of the harm caused because airpower affords no direct evidence of an attacker's state of mind. Any effort to avoid civilian harm is likely invisible to the civilian on the ground. A heavy reliance on airpower in a counterinsurgency campaign may thus be problematic, particularly for a belligerent who does not have a strong reputation for protecting civilians.

Second, individuals are also more likely to accept information that challenges their prior beliefs if it is emotionally shocking. ${ }^{84}$ Affective reactions to events are a source of evidence for the beliefs we form about them. ${ }^{85}$ As a result, in the face of a divergent schema, intentional and unnecessary harm may be more likely to be perceived correctly than unintentional and necessary harm. A civilian who believes that the coalition normally spares civilians will likely be shocked by an apparently intentional attack. Interestingly, interviewees who volunteered that the circumstances of an attack had contradicted their expectations of coalition troops' conduct were all in the group that deemed themselves intentional targets of attack. "We were told that Americans usually make the distinction [between civilians and combatants]. Not in this case. And for this they will be judged," 86 said one interviewee. Another posed the question: "I didn't think they killed civilians, but they shot three people outside the mosque. What else can that be? A mistake?" 87 Another interviewee saw it this way: "In general, their behavior isn't bad. But there are crazy soldiers among them. Being shot at made them crazy and so they targeted us." 88

The importance of affective reactions in the formation of beliefs about an attack also suggests that an obviously intentional attack may be more likely to change a civilian's prior beliefs about an attacker for the worse. By comparison, an actually 
unintentional attack may be less likely to lead to an improvement in civilians' views about a warring party, as it is more easily assimilated into their existing schema. Accordingly, interviewees who reported intentional harming sometimes highlighted that it had changed their previously favorable beliefs about the coalition. As one interviewee suggested, "The Americans showed good behavior in the beginning, but after they were challenged by the Taliban that changed. Now it seems like they are just shooting everywhere." ${ }^{\text {" }}$ Another asked: "They claim that they protect us, but how often can you make a mistake and it is still a mistake? I don't believe that anymore." 90

This tentative exploration of the correspondence between an attacker's conduct and the perceived circumstances of an attack suggests that we cannot always be sure that compliance with the legal rules of distinction and necessity means civilian casualties are perceived as unintended and unavoidable. However, consistent compliance with these legal rules is certainly an attacker's best option for achieving this goal. Moreover, affective and cognitive constraints on civilians' interpretation of an attacker's conduct also point toward the extraordinary strategic costs associated with obvious violations of international law: Violations may undermine civilians' correct interpretation of future legally compliant attacks. An attacker's compliance with distinction and necessity may therefore be crucial, though not sufficient, for the affected civilians' perception of harming as being relatively more legitimate and less blameworthy.

\section{Conclusion}

This article has shown that the moral principles of distinction and necessity informed the interviewed civilians' reaction to their own harming in war. Amending the prevailing view in the literature, this study found that the interviewed civilians did not uniformly blame their attacker. Instead, their attitudes were sensitive to the perceived circumstances under which they were harmed. Those who saw their harm as unintentional and unavoidable fully or partially blamed parties to the war other than the coalition. The study further offers some preliminary evidence that the moral principle of proportionality informed participants' abstract attitudes toward civilian casualties in Afghanistan. Further research might examine whether the perception of a belligerent's war aims as legitimate also informs civilians' reaction to their own harming and what civilians perceive as an appropriate balance between civilian casualties and an attack's 
contribution to the achievement of a legitimate war aim. Investigating the extent to which the uncovered divergences in civilians' attitudes translate into concrete differences in their behavior and, subsequently, into strategic outcomes is a further avenue for future research.

Moreover, this article has offered the first direct test of the assumption expressed in U.S. military doctrine that civilian casualties caused in compliance with international law stand a better chance of being perceived as legitimate by the local population. Although the findings presented here lend support to this assumption, they also point toward two caveats. First, the resonance of the international laws of war with civilians' attitudes may depend on the laws' convergence with underlying moral principles. The substantive demands of the legal rules of distinction and necessity, which accord with fundamental moral principles, were reflected in the civilians' attitudes in this study. The proposition that the legitimacy of civilian casualties depends partly on the importance of the military advantage that an attack pursues-the legal rule of proportionality-did not resonate with the civilians, in that they had not thought about the military importance of their attack when making sense of what happened to them. Second, affective and cognitive constraints on civilians' interpretations of an attacker's conduct may mean that an attack that complies with the rules of distinction and necessity will not always be perceived as unintentional and unavoidable. Thus, international law has an important, but ultimately limited, role to play in securing the perceived legitimacy of military force.

\section{SUPPLEMENTARY MATERIAL}

The supplementary material for this article can be found at https://doi.org/10. $1017 /$ So892679419000376

\section{NOTES}

${ }^{1}$ International Security Assistance Force, Tactical Directive, July 2, 2009, www.nato.int/isaf/ docu/official_texts/tactical_directive_090706.pdf; David Kilcullen, The Accidental Guerrilla: Fighting Small Wars in the Midst of a Big One (New York: Oxford University Press, 2009); John A. Nagl, "Learning to Eat Soup with a Knife: British and American Army Counterinsurgency Learning during the Malayan Emergency and the Vietnam War," World Affairs 161, no. 4 (Spring 1999), pp. 193-99; and Joint Chiefs of Staff, Joint Publication 3-24: Counterinsurgency (Washington, D.C.: Joint Chiefs of Staff, April 25, 2018), www.jcs.mil/Portals/36/Documents/Doctrine/pubs/jp3_24.pdf?ver=201805-11-102418-000; and Department of the Army, Insurgencies and Countering Insurgencies, FM 3-24, MCWP 3-33.5, (Washington, D.C.: Headquarters, Department of the Army, May 13, 2014), www.marines.mil/Portals/59/MCWP\%203-33.5_Part1.pdf.

${ }^{2}$ For this argument, see John Yoo, Point of Attack: Preventive War, International Law, and Global Welfare (New York: Oxford University Press, 2014), p. 9. Russia's military ventures are a notable exception. 
${ }^{3}$ U.S. Government Interagency Counterinsurgency Initiative, U.S. Government Counterinsurgency Guide (Washington, D.C.: U.S. Department of State, Bureau of Political-Military Affairs, January 2009), p. 31; Joint Chiefs of Staff, Joint Publication 3-24, p. III-24 [chapter 3, p. 24]; and Department of the Army, Insurgencies and Countering Insurgencies, pp. 1-1-1-11, $\$ \$ 1-1-1-38$. The U.S. Department of Defense's Law of War Manual likewise casts the goal of retaining the support of the local population as a reason for compliance with international law. It states that "the implementation and enforcement of the law of war are also supported by the fact that violations of the law of war are counterproductive to the political goals sought to be achieved by military operations. For example, violations of the law of war in counterinsurgency operations may diminish the support of the local population." U.S. Department of Defense, Department of Defense Law of War Manual (Washington, D.C.: General Counsel of the Department of Defense, updated December 2016), p. 1074.

4 Joint Chiefs of Staff, Joint Publication 3-24, p. VII-32.

${ }^{5}$ When referring to moral principles, this discussion refers to the now dominant account of justified killing in war based on reductive individualism. See Cécile Fabre, Cosmopolitan War (Oxford: Oxford University Press, 2012); and Jeff McMahan, Killing in War (Oxford: Oxford University Press, 2009). It derives principles for conduct in war from the principles that govern the permissibility of harming in general. These principles have been widely shown to inform ordinary citizens' attitudes toward harming in peacetime and therefore allow us to shed light on the extent to which "everyday moral commitments" inform civilians' attitudes toward their own harming in war. Moral principles, as understood here, are hence distinct from the principles of just war theory, which are derived from the deliberate theorization of permissible conduct specifically in war. For an account of how this intellectual tradition is committed to pragmatic, realist considerations, see Valerie Morkevičius, Realist Ethics: Just War Traditions as Power Politics (Cambridge, U.K.: Cambridge University Press, 2018).

6 This article relies on moral objectivism, a position that rejects the notion that the moral permissibility of killing is "in the eye of the beholder." It is worth stressing, however, that the relevance of the three moral principles that this study investigates does not stem from their objective validity, but from their resonance with popular attitudes toward peacetime harming, demonstrated so far mostly in Western societies.

7 The principle of distinction has two dimensions. One is the distinction between persons that are liable to harming and those that are not (who is a legitimate target?). The other dimension is the distinction between intentional and unintentional harming (what is the state of mind of the attacker?). The laws of war and reductive individualist moral principles give diverging answers to the first question. However, this paper focuses only on the second dimension of the principle of distinction: the role of intentionality in making harm more wrongful and blameworthy.

${ }^{8}$ I do not investigate whether civilians consciously draw on international law. The study examines whether moral principles inform, and whether legal rules resonate with civilians' attitudes. As explained, a legal rule resonates if its substantive demand is reflected in a civilian's attitude.

9 "Harm" here refers to physical injury or death, not mental trauma or property damage. The coalition, as understood here, includes forces belonging to the NATO-led ISAF (International Security Assistance Force) mission, operations Enduring Freedom and Resolute Support, and the Afghan National Defense and Security Forces (ANDSF). Although interviewees differentiated between international and Afghan troops, they universally referred to the former only as "Americans," even though they may have come in contact with British and Canadian forces as well.

${ }_{10}$ The failure of the legal rule of proportionality to resonate with the interviewed civilians' attitudes appears to be due to civilians not considering the importance of the military advantage an attack pursued when making sense of their attack. Alternatively, a legal rule could fail to resonate (in other words, its substantive demand could not be reflected in civilians' attitudes) because individuals actively reject its substantive proposition. Here this would mean civilians believe that the military importance of an attack should not matter for its legitimacy. I do not investigate whether the latter is the case.

${ }^{11}$ As I go on to explain, the association between the perceived circumstances of an attack and civilians' narratives or allocation of blame should not be thought of as indicative of a causal relationship.

12 Among others, see Christopher Gelpi, Peter D. Feaver, and Jason Reifler, Paying the Human Costs of War: American Public Opinion and Casualties in Military Conflicts (Princeton, N.J.: Princeton University Press, 2009); Robert Johns and Graeme A. M. Davies, "Civilian Casualties and Public Support for Military Action: Experimental Evidence," Journal of Conflict Resolution 63, no. 1 (January 2019), pp. 251-81; Sarah E. Kreps and Geoffrey P. R. Wallace, "International Law, Military Effectiveness, and Public Support for Drone Strikes," Journal of Peace Research 53, no. 6 (November 2016), pp. 830-44; Daryl G. Press, Scott D. Sagan, and Benjamin A. Valentino, "Atomic Aversion: Experimental Evidence on Taboos, Traditions, and the Non-Use of Nuclear Weapons," American Political Science Review 107, no. 1 (February 2013), pp. 188-206; and Scott D. Sagan and Benjamin 
A. Valentino, "Revisiting Hiroshima in Iran: What Americans Really Think about Using Nuclear Weapons and Killing Noncombatants," International Security 42, no. 1 (Summer 2017), pp. 41-79.

${ }^{13}$ Caleb Carr, The Lessons of Terror: A History of Warfare against Civilians (London: Little, Brown, 2002), p. 12. For studies that focus specifically on the use of deliberate violence against civilians by nonstate armed groups, see Max Abrahms, "Why Terrorism Does Not Work," International Security 31, no. 2 (Fall 2006), pp. 42-78; and Virginia Page Fortna, "Do Terrorists Win? Rebels' Use of Terrorism and Civil War Outcomes," International Organization 69, no. 3 (Summer 2015), pp. 519-56. For articles on the adverse strategic implications of civilian casualties caused by air strikes, see Matthew Adam Kocher, Thomas B. Pepinsky, and Stathis N. Kalyvas, "Aerial Bombing and Counterinsurgency in the Vietnam War," American Journal of Political Science 55, no. 2 (April 2011), pp. 201-18; and Robert A. Pape, Bombing to Win: Air Power and Coercion in War (Ithaca, N.Y.: Cornell University Press, 1996). For studies of the effects of civilian victimization specifically in insurgency/counterinsurgency operations, see Stathis N. Kalyvas, The Logic of Violence in Civil War (New York: Cambridge University Press, 2006); and Sebastian Schutte, "Violence and Civilian Loyalties: Evidence from Afghanistan," Journal of Conflict Resolution 61, no. 8 (September 2017), pp. 1595-625. For studies that, in opposition to the former, connect civilian victimization to military success, see Alexander B. Downes, "Draining the Sea by Filling the Graves: Investigating the Effectiveness of Indiscriminate Violence as a Counterinsurgency Strategy," Civil Wars 9, no. 4 (December 2007), pp. 420-44; and Jason Lyall, "Does Indiscriminate Violence Incite Insurgent Attacks? Evidence from Chechnya," Journal of Conflict Resolution 53, no. 3 (June 2009), pp. 331-62. For a rare exception of a direct study of civilians' attitudes, see Jason Lyall, Graeme Blair, and Kosuke Imai, "Explaining Support for Combatants during Wartime: A Survey Experiment in Afghanistan," American Political Science Review 107, no. 4 (November 2013), pp. 679-705.

${ }^{14}$ Luke N. Condra and Jacob N. Shapiro, "Who Takes the Blame? The Strategic Effects of Collateral Damage," American Journal of Political Science 56, no. 1 (January 2012), pp. 167-87; and Kalyvas, Logic of Violence in Civil War, p. 106.

${ }^{15}$ Kilcullen, Accidental Guerrilla; and Nagl, "Learning to Eat Soup with a Knife."

${ }^{16}$ Condra and Shapiro, "Who Takes the Blame?," p. 168.

17 Lyall, Blair, and Imai, "Explaining Support for Combatants during Wartime."

${ }^{18}$ Kalyvas, Logic of Violence in Civil War, p. $118 \mathrm{ff}$.

19 See Yitzhak Benbaji, Amir Falk, and Yuval Feldman, "Commonsense Morality and the Ethics of Killing in War: An Experimental Survey of the Israeli Population," Law \& Ethics of Human Rights 9, no. 2 (November 2015), pp. 195-227; Connor Huff and Joshua D. Kertzer, "How the Public Defines Terrorism," American Journal of Political Science 62, no. 1 (January 2018), pp. 55-71; and Scott D. Sagan and Benjamin A. Valentino, "Not Just a War Theory: American Public Opinion on Ethics in Armed Combat," International Studies Quarterly 62, no. 3 (September 2018), pp. 548-61.

${ }^{20}$ The stated aims of Operation Inherent Resolve in Iraq and Syria, for instance, include "defeat[ing] the ideology of ISIS," not merely defeating its military capacity. "About CTJF-OIR," Combined Joint Task Force-Operation Inherent Resolve, n.d., www.inherentresolve.mil/About-Us/.

${ }^{21}$ Joint Chiefs of Staff, Joint Publication 3-24, p. xiii. The U.S. Army's field manual, Insurgencies and Countering Insurgencies, describes insurgency and counterinsurgency as a "struggle for legitimacy." Department of the Army, Insurgencies and Countering Insurgencies, pp. 1-1-1-9, \$\$1-1-1-31, quote at p. $1-9$.

${ }^{22}$ Joint Publication 3-24 contains the caution that "in some contexts, populations have proven tolerant of increased civilian casualties as a result of aggressive offensive operations against insurgents when those operations helped produce a significant overall improvement in civil security. In other contexts, every civilian casualty resulting from COIN operations has undermined support for the government and its allies." Joint Chiefs of Staff, Joint Publication 3-24, p. III-13, \$5.

${ }^{23}$ Ibid, p. III-13.

${ }^{24}$ Ibid., p. VII-7.

25 Ibid., p. VII-32.

${ }^{26}$ Survey experiments with Western respondents consistently find that framing the use of force as illegal reduces support for it. See, among others, Stephen Chaudoin, "Promises or Policies? An Experimental Analysis of International Agreements and Audience Reactions," International Organization 68, no. 1 (January 2014), pp. 235-56; and Geoffrey P. R. Wallace, "International Law and Public Attitudes toward Torture: An Experimental Study,” International Organization 67, no. 1 (January 2013), pp. 105-40. For civilians in Iraq and Afghanistan to judge an attack as more legitimate because it conformed to international law, these civilians would have to be familiar not only with the existence of the laws of war but also with their precise content. This is highly unlikely. 
${ }^{27}$ Jutta Brunnée and Stephen J. Toope, Legitimacy and Legality in International Law (Cambridge, U.K.: Cambridge University Press, 2010), p. 271ff; Janina Dill, Legitimate Targets? Social Construction, International Law and US Bombing (Cambridge, U.K.: Cambridge University Press, 2015), p. 28f; and Martha Finnemore, "Are Legal Norms Distinctive?," New York University Journal of International Law and Politics 32, no. 3 (Spring 2000), pp. 699-706.

${ }^{28}$ For an investigation of the legitimacy of the laws of war, see Ian Clark, Sebastian Kaempf, Christian Reus-Smit, and Emily Tannock, "Crisis in the Laws of War? Beyond Compliance and Effectiveness," European Journal of International Relations 24, no. 2 (June 2018), pp. 319-43.

${ }^{29}$ Marc D. Hauser, Liane Young, and Fiery Cushman, "Reviving Rawls' Linguistic Analogy: Operative Principles and the Causal Structure of Moral Actions," in Walter Sinnott-Armstrong and Christian B. Miller, ed., Moral Psychology, Vol. 5, Virtue and Character (Oxford: Oxford University Press, 2008), pp. 107-79; Fiery Cushman, Liane Young, and Marc D. Hauser, "The Role of Conscious Reasoning and Intuition in Moral Judgment: Testing Three Principles of Harm," Psychological Science 17, no. 12 (January 2007), pp. 1082-89; and John Mikhail, "Universal Moral Grammar: Theory, Evidence, and the Future," Trends in Cognitive Sciences 11, no. 4 (May 2007), pp. 143-52.

${ }^{30}$ Compared to the fundamental moral principles associated with reductive individualism, the laws of war more faithfully reflect principles of conventional just war theory. The latter incorporates pragmatic as well as moral considerations. For a discussion of the relationship between the normative propositions of conventional just war theory and international law, see Valerie Morkevičius, "Looking Inward Together: Just War Thinking and Our Shared Moral Emotions," Ethics \& International Affairs 31, no. 4 (December 2017), pp. 441-51; and David Luban, "Just War Theory and the Laws of War as Nonidentical Twins," Ethics \& International Affairs 31, no. 4 (December 2017), pp. 433-440.

${ }^{31}$ In conducting the interviews for this study, I established that all interviewees met the definition of a "civilian" for the purposes of international law and had never directly participated in hostilities. As mentioned, this study does not investigate whom civilians perceive as liable to harming or immune from attack.

${ }^{32}$ See, for instance, Thomas A. Cavanaugh, "Double Effect and the End-Not-Means Principle: A Response to Bennett," Journal of Applied Philosophy 16, no. 2 (1999), pp. 181-185; Warren Quinn, "Actions, Intentions, and Consequences: The Doctrine of Double Effect," Philosophy and Public Affairs 18, no. 4 (1989), pp. 334-351.

${ }^{33}$ Hauser et al., "Reviving Rawls' Linguistic Analogy"; and John M. Mikhail, Elements of Moral Cognition: Rawls' Linguistic Analogy and the Cognitive Science of Moral and Legal Judgment (Cambridge, U.K.: Cambridge University Press, 2011).

34 The legal rule, enshrined in Article 57(2) (a) ii of the First Additional Protocol, tasks attackers with taking "all feasible precautions... with a view to avoiding, and in any event to minimizing" incidental civilian harm. It is sometimes referred to as the "precautionary principle." International Committee of the Red Cross (ICRC), Protocol Additional to the Geneva Conventions of 12 August 1949, and relating to the Protection of Victims of International Armed Conflicts (Protocol I), June 8, 1977, 1125 UNTS 3, available at: https://www.refworld.org/docid/3ae6b36b4.html

35 Justin W. Martin and Fiery Cushman, "Why We Forgive What Can't Be Controlled," Cognition 147 (February 2016), pp. 133-43.

${ }^{36}$ George P. Fletcher and Jens David Ohlin, Defending Humanity: When Force Is Justified and Why (New York: Oxford University Press, 2008), p. 20.

37 The legal rule and moral principle of proportionality not only propose that an attack that is expected to cause civilian casualties is more legitimate if it pursues a more important military advantage (the rule) and contributes to a morally just aim (the principle); they also, respectively, require a balance between the civilian harm associated with an attack and the importance of the military advantage and contribution of an attack to a just aim. In this study, I focus on the first dimension of the rule/principle only, as I explain later in the article.

${ }^{38}$ As previously noted, interviewees invariably referred to international forces as "Americans" even though some may well have encountered British and Canadian forces as well. Seventeen of the eighty-seven interviewed civilians thought they had been attacked by coalition forces involving Afghan troops.

39 Future research might fruitfully compare whether civilians hold different belligerent parties in a war to the same moral principles. In 2015 and the years leading up to it, more direct war-related civilian casualties in Afghanistan were caused by anti-government insurgent groups than by coalition forces. This trend has recently been reversed. See United Nations Assistance Mission in Afghanistan and United Nations of the High Commissioner for Human Rights, Afghanistan Annual Report on Protection of Civilians in Armed Conflict: 2015 (Kabul: United Nations Assistance Mission in Afghanistan, 2016), unama.unmissions.org/protection-of-civilians-reports; United Nations Security Council, "Protection 
of Civilians in Armed Conflict: Report of the Secretary-General," S/2019/373, May 7, 2019, unama. unmissions.org/protection-of-civilians-reports.

40 This is not to say that insurgent groups do not or should not follow codes of conduct inspired by ethical and legal thinking. For a rare systematic inquiry into this phenomenon, see Michael L. Gross, The Ethics of Insurgency: A Critical Guide to Just Guerilla Warfare (Cambridge, U.K.: Cambridge University Press, 2015).

${ }^{41}$ Interview with member of the Afghan Independent Human Rights Commission, April 25, 2015, Kabul. All interviews in this study were conducted confidentially and the interviewees' names withheld by agreement between both parties.

${ }^{42}$ For more information about the interview process, please consult the online supplement.

${ }^{43}$ I conducted the first half of the interviews myself. The second half were conducted by the translators alone without any foreigner in the room.

44 The need to repeat and explain questions in different ways would have made relying on a survey rather than interviews highly problematic.

${ }^{45}$ Many interviewees acknowledged that their reported age was a rounded estimate. Reported ages ranged from eighteen to eighty, with a median age of forty. The median age in the Afghan population is eighteen. Most public opinion polls in Afghanistan exclude women due to the difficulty of integrating them into a representative sample. Given that this study does not seek to make generalizable claims about the attitudes of all Afghans, but to uncover the process of how civilians affected by war form attitudes towards their own harming, I thought it was both possible and highly preferable not to exclude women's stories. Eighteen of the interviewees were women.

${ }^{46}$ Out of eighty-seven interviewees, one was half-Tajik and all the others identified as Pashtun. Both provinces are 99 percent Pashtun.

47 Antonio Giustozzi, Koran, Kalashnikov and Laptop: The Neo-Taliban Insurgency in Afghanistan (London: Hurst, 2007), pp. 46ff; and Hayder Mili and Jacob Townsend, "Tribal Dynamics of the Afghanistan and Pakistan Insurgencies," Combating Terrorism Center Sentinel 2, no. 8 (August 2009), pp. 1-4.

${ }^{48}$ The final section of this article addresses why some individuals may perceive an attack as unintentional while others perceive it as intentional.

49 Differences in moral judgments have, for instance, been linked to divergent thinking styles (Joshua D. Greene, "Why Are VMPFC Patients More Utilitarian?" A Dual-Process Theory of Moral Judgment Explains," Trends in Cognitive Sciences 11, no. 8 [August 2007], pp. 322-23); to empathy and perspective taking (Daniel M. Bartels and David A. Pizarro, "The Mismeasure of Morals: Antisocial Personality Traits Predict Utilitarian Responses to Moral Dilemmas," Cognition 121, no. 1 [October 2011], pp. 154-61); and to cognitive capacity (Adam B. Moore, Brian A. Clark, and Michael J. Kane, "Who Shalt Not Kill? Individual Differences in Working Memory Capacity, Executive Control, and Moral Judgment,” Psychological Science 19, no. 6 [July 2008], pp. 549-57).

50 If interviewees were unsure about what "intentional" or "deliberate" meant, we asked whether harming them was part of what they thought the coalition was trying to achieve with the attack.

${ }^{51}$ Female civilian, forty years old, Sangin, Helmand Province, July 30, 2015.

52 Male civilian, forty years old, Panjwayi, Kandahār Province, April 19, 2015.

53 Male civilian, forty-three years old, Zhari, Kandahār Province, April 20, 2015.

${ }^{54}$ Male civilian, thirty-nine years old, Gereshk, Helmand Province, April 21, 2015.

55 Male civilian, twenty-two years old, Gereshk, Helmand Province, April 21, 2015.

${ }^{56}$ Male civilian, eighty years old, Gereshk, Helmand Province, April 25, 2015.

57 Male civilian, thirty-five years old, Gereshk, Helmand Province, April 20, 2015.

${ }^{58}$ Janina Dill, "Supplementary Information about the Collection of Interview Data for 'Distinction, Necessity, and Proportionality: Afghan Civilians' Attitudes toward Wartime Harm,'” Online Supplement, Cambridge University Press, doi.org/10.1017/So892679419000376.

59 Female civilian, forty-five years old, Gereshk, Helmand Province, April 19, 2015.

${ }^{60}$ Female civilian, fifty-five years old, Sangin, Helmand Province, August 1, 2015.

${ }^{61}$ One interviewee reported being unsure about whom to blame.

${ }^{62}$ Male civilian, nineteen years old, Gereshk, Helmand Province, April 20, 2015.

${ }^{63}$ Male civilian, twenty-two years old, Gereshk, Helmand Province, April 21, 2015.

${ }^{64}$ As one interviewee described, "If they did respect our lives, they would have the war in the desert." Male civilian, forty-three years old, Zhari, Kandahār Province, April 20, 2015. According to another, "They don't respect us as human beings." Male civilian, thirty-five years old, Gereshk, Helmand Province, April 20, 2015.

65 Female civilian, fifty years old, Sangin, Helmand Province, April 20, 2015. According to another one of the interviewees: "The problem was they were just responding in the middle of the night. They were 
shooting from wherever they received fire." Male civilian, fifty-five years old, Sangin, Helmand Province, July 28, 2015. And, as another woman explained, "You do not know what the war in Helmand is like. It was not possible to distinguish as the Taliban had coerced us into accepting them into our houses." Female civilian, seventy years old, Kajaki, Helmand Province, April 20, 2015.

${ }_{66}^{66}$ Male civilian, twenty-two years old, Sangin, Helmand Province, July 30, 2015.

67 Male civilian, forty-eight years old, Sangin, Helmand Province, April 20, 2015. As another of the interviewees saw it: "They have very good technology. I am sure they can separate the Taliban if they want." Male civilian, twenty-eight years old, Sangin, Helmand Province, July 29, 2015. And another put it this way: "They have modern planes. So, they could be more careful." Male civilian, twenty-seven years old, Sangin, Helmand Province, July 29, 2015.

${ }^{68}$ Male civilian, forty-seven years old, Sangin, Helmand Province, July 28, 2015.

69 When interviewees did not understand what we meant by "a legitimate aim," we asked about peace and stability in their province or district or the country at large. We counted a yes to any of these questions as the recognition of a legitimate aim.

${ }^{70}$ Seventy-seven percent of the interviewed civilians attributed a legitimate aim to Afghan government forces and five percent to the Taliban. Eighteen percent thought none of the parties had a legitimate overall aim.

${ }^{71}$ Ten interviewees either ended the interview before we reached this abstract question or did not fully understand it.

${ }_{72}$ Male civilian, nineteen years old, Sangin, Helmand Province, April 23, 2015.

${ }_{73}$ Male civilian, twenty years old, Gereshk, Helmand Province, April 23, 2015.

74 Male civilian, twenty-two years old, Gereshk, Helmand Province, April 21, 2015.

75 Male civilian, fifty years old, Sangin, Helmand Province, April 21, 2015.

${ }^{76}$ Male civilian, eighteen years old, Sangin, Helmand Province, April 23, 2015.

77 Male civilian, thirty-two years old, Sangin, Helmand Province, July 28, 2015.

${ }^{78}$ Legally speaking, the substance of an attack's aim, such as whether it is directed against combatants or seeks to achieve a military advantage, is a matter of distinction. The military importance of the aim (compared to the expected civilian harm) determines its proportionality.

79 It is important to note that this question was only asked in the first half of the interviews (forty-seven of the reported interviews). The question often confused and sometimes upset interviewees, which is why I instructed the translators not to ask it in the interviews they conducted on their own.

${ }^{80}$ For the role of cognitive schemas and analogies in shaping the interpretation of political events, see Christopher M. Hemmer, Which Lessons Matter? American Foreign Policy Decision Making in the Middle East, 1979-1987 (Albany, N.Y.: State University of New York Press, 2000); David Patrick Houghton, "Historical Analogies and the Cognitive Dimension of Domestic Policymaking," Political Psychology 19, no. 2 (June 1998), pp. 279-303; and Yuen Foong Khong, Analogies at War: Korea, Munich, Dien Bien Phu, and the Vietnam Decisions of 1965 (Princeton, N.J.: Princeton University Press, 1992). For a theorization of the role of schemas and related concepts in cognitive processing, see Susan T. Fiske and Patricia W. Linville, "What Does the Schema Concept Buy Us?," Personality and Social Psychology Bulletin 6, no. 4 (December 1980), pp. 543-57.

${ }^{81}$ Phillip E. Tetlock, "Close-Call Counterfactuals and Belief System Defenses: I Was Not Almost Wrong, But I Was Almost Right," Journal of Personality and Social Psychology 75, no. 3 (September 1998), pp. 639-52.

82 As mentioned previously, how the perceived circumstances of an attack affect civilians' attitudes is unlikely to be systematically different for individuals with different demographic backgrounds. In contrast, how individuals perceive similar circumstances may well systematically vary with demographic factors that are correlated with political preferences and ideological commitments.

${ }^{83}$ Jonathan Mercer, "Rationality and Psychology in International Politics," International Organization 59, no. 1 (Winter 2005), pp. 77-106; and Deborah Welch Larson, "The Role of Belief Systems and Schemas in Foreign Policy Decision-Making," in "Political Psychology and the Work of Alexander L. George," special issue, Political Psychology 15, no. 1 (March 1994), pp. 17-33.

${ }^{84}$ Janice Gross Stein, "Foreign Policy Decision Making: Rational, Psychological, and Neurological Models," in Steve Smith, Amelia Hadfield, and Tim Dunne, eds., Foreign Policy: Theories, Actors, Cases (Oxford: Oxford University Press, 2008), p. 135; and Robert Jervis, Perception and Misperception in International Politics (Princeton, N.J.: Princeton University Press, 1976), p. $288 \mathrm{ff}$.

${ }^{85}$ Neta C. Crawford, "Homo Politicus and Argument (Nearly) All the Way Down: Persuasion in Politics," Perspectives on Politics 7, no. 1 (March 2009), pp. 103-24; and Jonathan Mercer, "Emotional Beliefs," International Organization 64, no. 1 (January 2010), pp. 1-31.

${ }^{86}$ Male civilian, forty-three years old, Zhari, Kandahār Province, April 20, 2015.

${ }^{87}$ Male civilian, thirty-five years old, Gereshk, Helmand Province, April 20, 2015. 
${ }^{88}$ Male civilian, thirty years old, Sangin, Helmand Province, April 18, 2015.

${ }^{89}$ Male civilian, forty-eight years old, Sangin, Helmand Province, April 19, 2015. As another man explained, "I used to think, maybe they are good, but now, how can I forgive them now?" Male civilian, fifty years old, Sangin, Helmand Province, April 21, 2015.

${ }^{\circ}$ Male civilian, forty years old, Panjwayi, Kandahār Province, April 19, 2015.

Abstract: How do civilians react to being harmed in war? Existing studies argue that civilian casualties are strategically costly because civilian populations punish a belligerent who kills civilians and support the latter's opponent. Relying on eighty-seven semi-structured interviews with victims of coalition attacks in Afghanistan, this article shows that moral principles inform civilians' attitudes toward their own harming. Their attitudes may therefore vary with the perceived circumstances of an attack. Civilians' perception of harm as unintended and necessary, in accordance with the moral principles of distinction and necessity, was associated with narratives that cast an attack as relatively more legitimate and with a partial or full release of the coalition from blame. The principle of proportionality, which requires that civilian casualties are caused in pursuit of a legitimate war aim, informed their abstract attitudes toward civilian casualties in Afghanistan. Two rules of international law, which accord with the moral principles of distinction and necessity, were reflected in the civilians' attitudes. The legal rule of proportionality, which diverges from the namesake moral principle, failed to resonate with the civilians. The article explores whether compliance with the legal rules of distinction and necessity can contribute to mitigating the strategic costs of civilian casualties.

Keywords: distinction, necessity, proportionality, civilian casualties, attitudes toward harm, international law, moral principles, counterinsurgency operations, Afghanistan 